\title{
Magnetic Resonance Enterography Findings and Correlation of Apparent Diffusion Coefficient Values with Clinical Response in Inflammatory Bowel Disease Patients
}

\section{Inflamatuvar Bağırsak Hastalıklarında Manyetik Rezonans Enterografi Bulguları ve Apparent Diffusion Coefficient Değerlerinin Klinik Cevap ile Korelasyonu}

Seyit Erol ${ }^{1}$,

Ramazan Dertli²

Mehmet Asil',

Yusuf Kenan Boyraz ${ }^{3}$

Ulku Kerimoglu ${ }^{1}$,

${ }^{1}$ Necmettin Erbakan University, Meram Faculty of Medicine, Department of Radiology, Konya, Turkey

${ }^{2}$ Necmettin Erbakan University, Meram Faculty of Medicine, Department of Gastroenterology, Konya, Turkey

${ }^{3}$ Necmettin Erbakan University, Meram Faculty of Medicine, Department of Public Health, Konya, Turkey

Geliş Tarihi/Received: 19 February 2020 Kabul Tarihi/Accepted: 17 July 2020

Address correspondence to: Seyit Erol, Necmettin Erbakan University, Meram Faculty of Medicine, Department of Radiology, Konya, Turkey

e-mail: seyiterol42@gmail.com

\section{ORCID}

Seyit Erol

https://orcid.org/0000-0002-0547-872X

Ramazan Dertli

https://orcid.org/0000-0002-6205-8983

Mehmet Asil

https://orcid.org/0000-0001-7332-686X

Yusuf Kenan Boyraz

https://orcid.org/0000-0002-6463-7532

Ulku Kerimoglu

https://orcid.org/0000-0002-2733-7696
Öz

Amaç: Inflamatuar Barsak Hastalığı(IBH) tanılı aktif bulguları olan ve remisyondaki hastalar arasında MR Enterografi ve Difüzyon MR incelemelerinin ilișkisini değerlendirmektir.

Hastalar ve Yöntem: Çalışmamıza, hastanemizde 01.12.2015 ve 31.08.2016 tarihleri arasında IBH tanısı olan hastalar dahil edilmiştir. Hastalara yağ baskılı T2 trufi ve difüzyon ağırlıklı görüntüleme sekansları alınmıştır. Daha sonra intravenöz kontrast madde sonrası 60. saniyede T1 ViBE sekansları alınmıştır. 47 hastanın 1. grup olan 10 tanesinde aktif ve remisyonda MR incelemeleri olup, 2. gruptaki 37 hastanın ise aktif ve inflame olmayan barsak duvarından ADC, duvar kalınlıkları ve kontrastlanma miktarları karşılaştırıldı.

Bulgular: Toplam 47 hasta olup bunların 30'u erkek (\%63,8), 17'si kadındır $(\% 36,2)$. Hastaların 32'sinde $(\% 68,1)$ Ülseratif kolit, 15 'inde $(\% 31,9)$ Crohn hastalığı vardır. Birinci grupta aktif ve remisyon MR incelemelerindeki ADC değerleri ile aktif ve remisyondaki duvar kalınlıkları arasında istatistiksel olarak anlamlı farklılık bulundu $(p=0,005)$. Birinci grupta aktif ve remisyondaki barsak duvar kontrastlanmaları arasında istatistiksel olarak anlamlı fark bulunmadı $(p=0,059)$. Ikinci gruptaki aktif ve normal barsaktan ADC değerleri, duvar kalınlıkları ve kontrastlanmalarında da istatistiksel olarak anlamlı farklılık bulundu $(p<0,001)$.

Sonuç: MR Enterografi ve Difüzyon MR incelemesi bu hastalardaki inflamasyonun derecesi ve tedaviye yanıtın belirlenmesinde yararlı olabilir.

Anahtar Kelimeler: Inflamatuar barsak hastalıkları, MR enterografi, difüzyon MR

Abstract

Aim: We aimed to evaluate the relationship between magnetic resonance (MR) enterography and diffusion magnetic resonance imaging (MRI) investigations in inflammatory bowel disease (IBD) patients during active inflammation and remission phases.

Patients and Methods: We included patients diagnosed with IBD between 01.12.2015-31.08.2016 at our hospital. Standard institutional sequences for upper and lower abdomen scan included: sagittal and axial T2 TRUFI, axial and coronal fat suppressed T2 TRUFI and coronal and axial T1 VIBE following intravenous (at 60 seconds) contrast medium administration. First group of patients $(n=10)$ had MRI investigations both at active and remission phases, whereas in the second group of patients $(n=37)$ apparent diffusion coefficient (ADC) values, bowel wall thickness and contrast enhancement grades were compared between actively inflamed and non-inflamed bowel segments.

Results: 47 patients were included; 30 were male $(63.8 \%)$ and 17 were female $(36.2 \%)$. Thirty two $(68.1 \%)$ of them had ulcerative colitis and $15(31.9 \%)$ had Crohn's disease. A statistically significant difference was found regarding ADC values and bowel wall thickness measurements in the first group of patients when compared between active and remission phase MRI investigations $(p=0.005)$. Bowel wall contrast enhancement degree did not differ between active and remission phases in the first group $(p=0.059)$. In the second group, there was a statistically significant difference between active and normal bowel segments regarding ADC values, bowel wall thickness and contrast enhancement $(p<0.001)$.

Conclusion: MR enterography and diffusion MRI may be beneficial to determine the degree of inflammation and response to treatment in IBD patients.

Key words: Inflammatory bowel disease, MR enterography, diffusion MRI
Cite this article as: Erol S, Dertli R, Asil M, Boyraz YK, Kerimoglu U. Magnetic Resonance Enterography Findings and Correlation of Apparent Diffusion Coefficient Values with Clinical Response in Inflammatory Bowel Disease Patients. Selcuk Med J 2021;37(1): 70-76 Disclosure: None of the authors has a financial interest in any of the
products, devices, or drugs mentioned in this article. The research was
not sponsored by an outside organization. All authors have agreed to allow
full access to the primary data and to allow the journal to review the data
if requested. 


\section{INTRODUCTION}

Inflammatory bowel disease (IBD) is a chronic idiopathic inflammatory disease of the bowels. Two major types of IBD are Crohn's disease and ulcerative colitis. Ulcerative colitis involves colonic mucosa in a diffuse pattern, whereas Crohn's disease can affect any segment of the gastrointestinal tract in a patchy pattern and the bowel wall involvement is transmural. Both diseases course with remissions and exacerbations (1). Definite diagnosis of IBD is made by endoscopy and biopsy (2). However, the hardly accessible localization and long, tortuous anatomy of the small intestine precludes endoscopic and radiologic assessment. Endoscopy enables the evaluation of the esophagus, stomach and small intestine up to jejunum, whereas colonoscopy provides information about colon and terminal ileum. In addition, balloon enteroscopy and capsule endoscopies are methods used for the small intestine. Therefore, radiologic imaging modalities are of significance for the diagnosis of IBD (2).

Main radiologic imaging modalities used to evaluate the intestines include small intestine enema examination, conventional enteroclysis, ultrasonography, computed tomography (CT) and magnetic resonance imaging (MRI) (3). Recently, CT and MR enteroclysis-enterography have been the preferred methods since they combine the advantages of conventional and cross-sectional imaging. These provide valuable information about the adjacent tissues, as well as the bowel wall, and also enable the diagnosis of intraabdominal complications that may accompany the disease. The apparent diffusion coefficient (ADC) value, which is the quantitative measurement of the intercellular water diffusion, is acquired from diffusion MRI and this provides information about conditions in which cellularity is increased and intercellular water diffusion is limited, such as malignancies and inflammation. In this study, we aimed to compare bowel wall thickness, contrast enhancement patterns, and ADC measurements obtained from MR enterography and diffusion MRI between the diseased and normal bowel segments at the active and remission phases of the disease in subjects diagnosed with IBD.

\section{PATIENTS AND METHODS Patients}

In our study, patients who came to our hospital with an active complaint and diagnosed as inflammatory bowel disease clinically, endoscopically and histologically between 1 December 2015 and 31 August 2016 were included in the study. These patients underwent MR enterography with diffusion for the radiological examination. A total of 47 patients (30 male, 17 female; mean age: 42.8 years; range: $20-77$ years) were included. Thirty two $(68.1 \%)$ of them had ulcerative colitis and 15 (31.9\%) had Crohn's disease. Local ethics committee approval was obtained (No: 2016/526).

\section{Magnetic Resonance Imaging Protocol}

MR enterography and diffusion MRI were performed on a 1.5T MR system (Siemens Aera, Siemens Medical Solutions, Erlangen, Germany). $2000 \mathrm{~mL}$ of water was ingested 1 hour before MRI to distend the bowels. MRI scan was initiated following confirmation of adequate distension in the pilot scan. Standard institutional sequences for upper and lower abdomen scan included: Sagittal and axial T2 TRUFI, axial and coronal fat suppressed T2 TRUFI and coronal and axial T1 VIBE following intravenous (at 60 seconds) gadolinium-based contrast medium (gadopentetate dimeglumine) (Magnevist) administration at 0.1 $\mathrm{mmol} / \mathrm{kg}$. Prior to contrast administration, spin echoweighted images in the axial plane $\left(b=50 \mathrm{sec} / \mathrm{mm}^{2}\right.$, $b=400 \mathrm{sec} / \mathrm{mm}^{2}$ and $b=800 \mathrm{sec} / \mathrm{mm}^{2}$ ) were obtained.

Scan parameters were as follows: for T2 TRUFI ; repetition time (TR): $806,6 \mathrm{msec}$, echo time (TE): 2,13 msec, field of view (FOV): $390 \mathrm{~mm}$, slice thickness: 4 $\mathrm{mm}$; for coronal fat suppressed T2 TRUFI; TR: 599 ms, TE: 2,13 ms, FOV: $400 \mathrm{~mm}$, slice thickness: 4 $\mathrm{mm}$; for axial fat suppressed T2 TRUFI; TR: 549,1 ms, TE: $2,1 \mathrm{~ms}$, FOV: $380 \mathrm{~mm}$, slice thickness: $5 \mathrm{~mm}$; for diffusion-weighted imaging; TR: $5500 \mathrm{~ms}$, TE: 56 ms, FOV: $380 \mathrm{~mm}$, slice thickness: $6 \mathrm{~mm}$; for postcontrast coronal T1- volumetric interpolated breathhold examination (VIBE); TR: 6,6 msec, TE: 2,3 msec, FOV: $450 \mathrm{~mm}$, slice thickness: $1,8 \mathrm{~mm}$; for postcontrast axial T1-VIBE TR: $6,6 \mathrm{msec}$, TE: $2,3 \mathrm{msec}$, FOV: $400 \mathrm{~mm}$, slice thickness: $2 \mathrm{~mm}$. Scan lasted approximately 15 minutes. Bowel wall thickness and degree of contrast enhancement were determined using conventional and contrast MRI investigations. $A D C$ values were measured using diffusion-weighted imaging. ROI area for ADC measurement was 3,158 $\mathrm{mm}^{2}$.

\section{Magnetic Resonance Imaging Analysis}

1. Patients were evaluated in two groups. First group of patients $(n=10)$ had two separate MR enterography and diffusion-weighted MRI scans taken at active and remission phases (1-9 months after first MRI scan). ADC and wall thicknesses were 


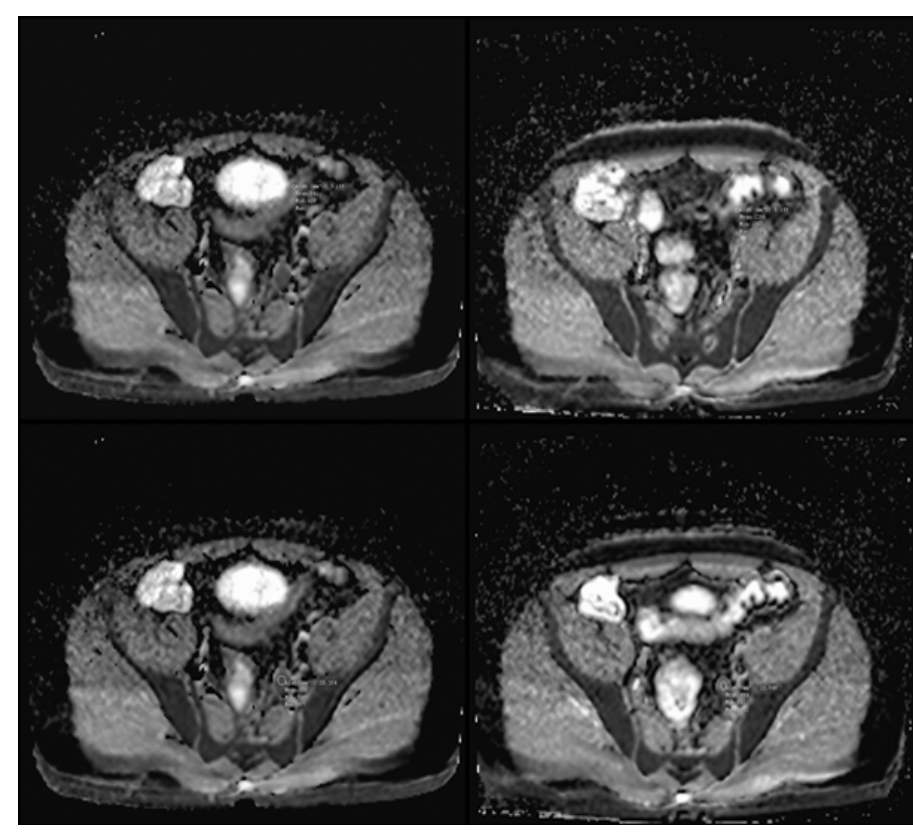

Figure 1A-B-C-D. A 36-year-old man with known ulcerative colitis involving sigmoid colon.

Figure 1A (top left): Inflamed sigmoid ADC values $941 \times 10^{-6}$ $\mathrm{mm}^{2} / \mathrm{sec}$

Figure 1B (top right): Sigmoid in remission phase ADC values $1290 \times 10^{-6} \mathrm{~mm}^{2} / \mathrm{sec}$

Figure $1 \mathrm{C}$ (bottom left): Left parailiac lymph node in active phase ADC values $806 \times 10^{-6} \mathrm{~mm}^{2} / \mathrm{sec}$

Figure 1D (bottom right): Left parailiac lymph node in remission phase ADC values $994 \times 10^{-6} \mathrm{~mm}^{2} / \mathrm{sec}$

measured quantitatively from two local bowel walls that were colonoscopically active from 10 patients in the first group and from these localizations in remission MR examination. Same examinations were also undertaken at the remission phase from the same segments. Minimum values of each parameter were taken into consideration at the time of statistical analysis. Because there was no significant difference between median ADC values obtained from two separate bowel segments that showed active inflammation $(p=0.959)$.

2. Second group of patients $(n=37)$ had ADC measurements performed quantitatively from two different locations from the colonoscopically active bowel wall. Due to the presence of a short bowel segment with active inflammation, a single measurement was done in 4 patients (2 males and 2 females). Since colonoscopic and radiologic evaluation revealed diffuse inflammation in the whole

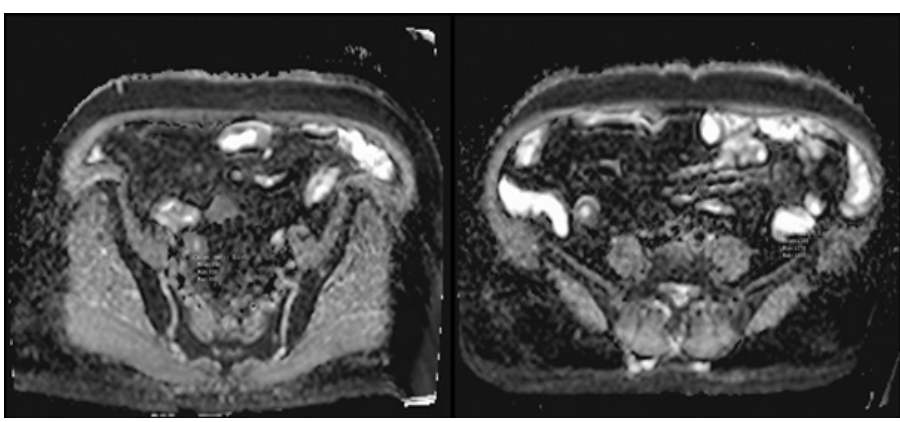

Figure 2A-B. A 65-year-old woman with known Crohn's disease.

Figure 2A (left): Inflamed sigmoid ADC values $840 \times 10^{-6} \mathrm{~mm}^{2} /$ sec

Figure 2B (right): Normal descending colon ADC values 1285 $x 10^{-6} \mathrm{~mm}^{2} / \mathrm{sec}$

colon of 2 patients ( 1 male and 1 female) normal ADC and wall thickness measurements could not be performed in these patients and 35 subjects were included in the analysis. Single ADC, wall thickness measurements were obtained from bowel segments that were confirmed to be normal by colonoscopy and conventional MRI examinations. Regarding ADC and wall thickness, minimum values obtained from bowel segments with active inflammation and single values obtained from normal bowel segments were compared. Mural enhancement greater than adjacent normal bowel wall was graded as mild, moderate if the signal intensity was less than iliac arteries and severe if equal to iliac arteries was graded and these grades were compared in both groups. 3 of 37 patients in the second group had no contrast enhanced investigations. Therefore, degree of contrast enhancement was evaluated in 34 patients. In addition, since colonoscopy and radiologic evaluation revealed diffuse inflammation in the whole colon of 2 patients in the second group, normal contrast enhancement measurements could not be performed in these patients and 32 subjects were included in the analysis.

3. Among 47 patients included as the patient group, 2 patients ( 1 male and 1 female) were excluded since normal ADC and wall thickness measurements were not performed in these patients due to diffuse inflammation involving the whole colon detected using colonoscopy and radiologic methods. ADC in the active bowel segments was compared with ADC 


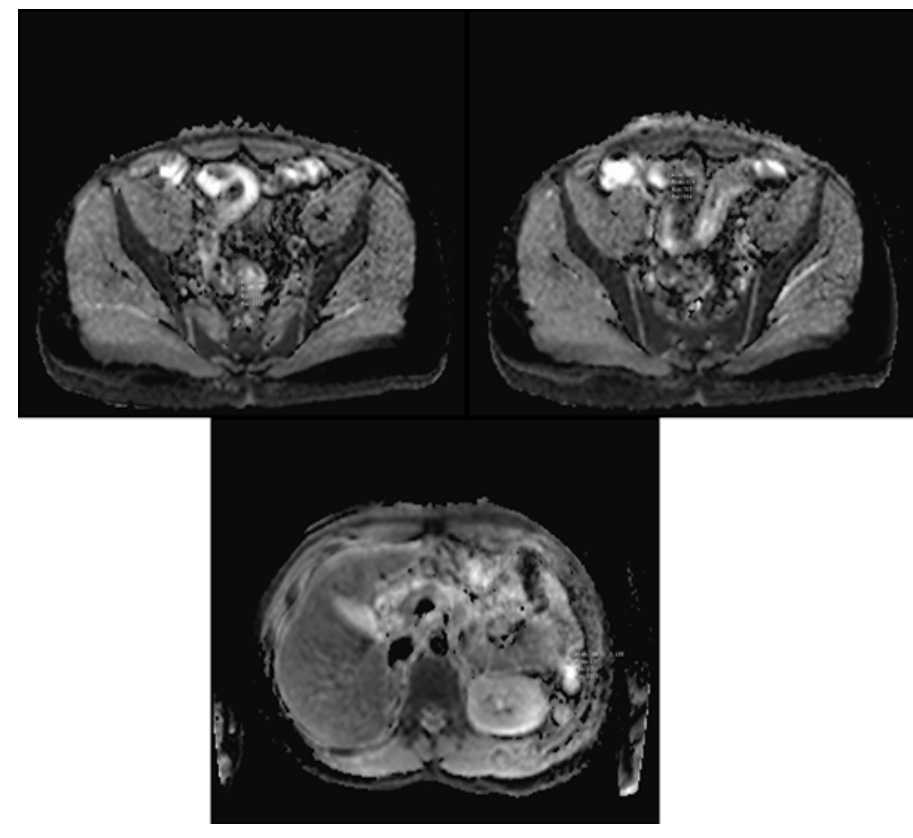

Figure 3A-B-C. A 31-year-old man with known Crohn's disease.

Figure 3A (top left): Inflamed rectum ADC values $966 \times 10^{-6}$ $\mathrm{mm}^{2} / \mathrm{sec}$

Figure 3B (top right): Inflamed sigmoid ADC values $824 \mathrm{x}$ $10^{-6} \mathrm{~mm}^{2} / \mathrm{sec}$

Figure 3C (bottom): Normal descending colon ADC values $1397 \times 10^{-6} \mathrm{~mm}^{2} / \mathrm{sec}$

during the remission phase in the first group of patients and ADC obtained from normal bowel segments of second group of patients. Bowel wall thickness measurements were performed in 45 patients from the same localizations where ADC had been measured and were compared. Degree of contrast enhancement was evaluated in 44 subjects, since 3 of 47 patients (1 male and 2 females) did not have contrast enhanced investigations. In addition, since colonoscopic and radiologic evaluation revealed diffuse inflammation in the whole colon of 2 patients ( 1 male and 1 female), normal contrast enhancement measurements could not be performed in these patients, and 42 subjects underwent evaluation of contrast enhancement in normal/ at remission bowel segments.

\section{Statistical analysis}

Statistical analyses were performed using IBM SPSS Statistics 18.0 program. In addition to the descriptive statistical methods (mean, standard deviation), Wilcoxon test was used to compare nonnormally distributed non-parametric data. Normally distributed data was compared using either paired samples t-test in related samples or student's t-test in independent samples. Chi-squared test was used to compare categorical variables such as bowel wall contrast enhancement. A p value $<0.05$ denoted a statistically significant difference.

\section{RESULTS}

\section{Comparison of active and remission phases}

In the first group, there was a statistically significant difference between mean ADC values obtained from MRI scans at the time of active and remission phases $\left(811.8 \times 10^{-6}\right.$ vs. $1111.6 \times 10^{-6} \mathrm{~mm}^{2} / \mathrm{sec}$, respectively, $p=0.005)$. In the first group, there was also a statistically significant difference between mean wall thickness measurements obtained from MRI scans at the time of active and remission phases (7.25 and 5.1 $\mathrm{mm}$, respectively, $\mathrm{p}=0.007)$. Evaluation of contrast enhancement in the first group during the active phase revealed mild enhancement in $6(60 \%)$, moderate enhancement in $3(30 \%)$ and severe enhancement in $1(10 \%)$ patients. At remission phase, all patients had mild contrast enhancement. No statistically significant difference was detected between active and remission phase measurements $(p=0.059)$. (Table 1$)$.

\section{Comparison between normal and inflamed bowel segments}

In the second group, there was a statistically significant difference in mean ADC values obtained from inflamed and normal bowel segments 35 patients $\left(848.2 \times 10^{-6}\right.$ vs. $1434.97 \times 10^{-6} \mathrm{~mm}^{2} / \mathrm{sec}$, respectively, $\mathrm{p}<0.001)$.

There was a statistically significant difference between mean wall thickness of inflamed and normal bowel segments $(6,5$ vs. $3.7429 \mathrm{~mm}$, respectively, $p<0.001)$. There was a statistically significant

Table 1. Comparison of ADC, bowel wall thickness and contrast enhancement parameters in the first group

\begin{tabular}{llll}
\hline First group $(\mathbf{n}=\mathbf{1 0})$ & Active bowel wall & Remission bowel wall & p-value \\
\hline ADC $\left(\times 10^{-6} \mathrm{~mm}^{2} / \mathrm{sec}\right)$ & $811.8 \pm 133.5$ & $1111.6 \pm 201.5$ & .005 \\
Wall thickness $(\mathrm{mm})$ & $7.25 \pm 1.5$ & $5.1 \pm 2$ & .007 \\
Enhancement mild/moderate/severe $(\%)$ & $60 / 30 / 10$ & $100 /-/-$ & .059 \\
\hline A & & &
\end{tabular}

Abbreviation: ADC: Apparent diffusion coefficient 
Table 2. Comparison of ADC, bowel wall thickness and contrast enhancement parameters in the second group

\begin{tabular}{llll}
\hline Second group $(\mathbf{n}=\mathbf{3 7})$ & Active bowel wall & Normal bowel wall & p-value \\
\hline $\mathrm{ADC}\left(\times 10^{-6} \mathrm{~mm}^{2} / \mathrm{sec}\right)$ & $848,2 \pm 127,4$ & $1434,97 \pm 209,4$ & $<.001$ \\
Wall thickness $(\mathrm{mm})$ & $6,5 \pm 1,2$ & $3,74 \pm 0,8$ & $<.001$ \\
Enhancement mild/moderate/severe(\%) & $50 / 38,2 / 11,8$ & $100 /-/-$ & $<.001$ \\
\hline
\end{tabular}

Abbreviation: ADC: Apparent diffusion coefficient

difference regarding contrast enhancement between inflamed and normal bowel segments $(p<0.001)$. Among 34 patients, 17 (50\%) had mild, 13 (38.2\%) had moderate and $4(11.8 \%)$ had severe contrast enhancement in the inflamed bowel segments. In the normal bowel segments, all patients $(100 \%)$ had mild contrast enhancement (Table 2).

\section{Comparison in all patients}

A statistically significant difference was detected between mean ADC values of inflamed bowel segments and normal/at remission bowel segments $\left(840.11 \times 10^{-6}\right.$ vs. $1363.11 \times 10^{-6} \mathrm{~mm}^{2} / \mathrm{sec}$, respectively, $p<0.001)$. There was a statistically significant difference regarding bowel wall thickness measurements between inflamed and normal/ at remission bowel segments (6.67 vs. $3.9333 \mathrm{~mm}$, respectively, $p<0.001)$. A statistically significant difference regarding contrast enhancement degrees between inflamed and normal/ at remission bowel segments was found $(p<0.001)$. Among 44 patients, $23(52.3 \%)$ had mild, $16(36.4 \%)$ had moderate and $5(11.4 \%)$ had severe contrast enhancement in the inflamed bowel segments. Contrast enhancement in normal/ at remission bowel segments was mild in all patients (100\%).

\section{DISCUSSION}

In this study, we compared bowel wall thickness, degree of contrast enhancement and ADC values obtained from MR Enterography and Diffusion MRI in patients diagnosed with IBD during the active and remission phases. When compared to remission phase, ADC was lower and bowel wall was thicker in the affected bowel segments during the active phase of the disease. In addition, during the active phase of the disease affected bowel segments had increased bowel wall thickness and contrast enhancement and reduced ADC compared to normal bowel segments. Radiologic assessment in IBD targets early diagnosis of the disease and intra-extraluminal complications, as well as assessment of the disease extent. Fastsequence MRI studies and MR enterography have facilitated the diagnosis of pathologies that are hard to assess due to their localizations and extraluminal complications (4). MR enterography provides information for the diagnosis of complications, such as increased bowel wall thickness, stenosis, fistula and abscess formation, which are hardly detectable using endoscopy, and also for the management of the disease. Clinical and laboratory data are nonspecific for determination of the disease activity in IBD. Besides colonoscopic and pathologic investigations, MR enterography do provide important findings for determining the disease course (5). A study has reported that the degree of contrast enhancement at the terminal ileum was associated with clinical and endoscopic determinants of disease activity (6). Following the transition from the active phase to the remission phase, bowel wall contrast enhancement is known to be similar to that of the normal bowel wall. On the other hand, increase in bowel wall thickness persists. In the acute phase, wall thickness is increased due to edema and inflammation, whereas it is caused by fibrosis in the chronic phase (7).

Although Gore et al. (8) has reported that the target shaped contrast enhancement in the bowel wall is a good marker of active inflammation, its specificity and sensitivity are unknown. During the active phase, the inflamed mucosa retains more contrast compared to the submucosa. Due to lipid retention in the submucosa, target appearance may still be present during the chronic remission phase. Lipid content in the submucosal layer helps differentiating the active/ remission phases in patients with target appearance (9).

In 88 patients diagnosed with Crohn's disease, Qi et al. have compared bowel wall thickness and degree of contrast enhancement using MR enterography at the active and remission phases of the disease. A statistically significant difference was found regarding both bowel wall thickness $(8.2 \pm 2.6 \mathrm{~mm}$ at the active phase vs. $5.5 \pm 1.6 \mathrm{~mm}$ at the remission phase, $p<0.01$ ) and degree of contrast enhancement $(112 \pm 16 \mathrm{HU}$ at the active phase vs. $93 \pm 17 \mathrm{HU}$ at the remission phase, $p<0.01)(10)$. In accordance with the previous data, our study has also demonstrated statistically 
significant difference regarding bowel wall thickness when compared between normal and diseased bowel segments, as well as between diseased bowel segments at active and remission phases. Degree of contrast enhancement did not differ in the first group of patients. This may be due to the limited number of patients or presence of severe enhancement in only one patient during the active phase of the disease. A statistically significant difference in contrast enhancement independent from gender was found in the second group of patients and the whole study population, similar to previous observations.

Diffusion MRI is frequently being used for the early diagnosis of ischemic stroke and the differential diagnosis of acute/chronic stroke. In addition, it is used in cancer patients to localize tumors, discrimination of tumors from healthy tissue and to evaluate the response to treatment (11). It is also recently being used in IBD patients. Following assessment of 171 small intestine segments in 44 patients diagnosed with Crohn's disease, Seo et al. (12) have reported that sensitivity and specificity of MR enterography and diffusion MRI to detect terminal ileum inflammation did not differ. This data demonstrates the value of diffusion $\mathrm{MRI}$ in the detection of bowel wall inflammation. Kim et al. (13) have shown that MR enterography combined with diffusion MRI is more sensitive than only MR enterography to detect bowel wall inflammation. However, its specificity was lower due to the false positivity in the colorectum. This study has also suggested that diffusion MRI was beneficial to discriminate the more severe inflammation in the bowel segments showing active inflammation in the MR enterography.

In another study that evaluated 20 patients diagnosed with Crohn's disease who had histopathologically documented terminal ileum involvement, ADC values were compared between terminal ileum and normal ileal segments using MR enterography including diffusion MRI. Sensitivity and positive predictive value of diffusion MRI to detect inflammation were found to be $100 \%$. In this study, ADC values obtained from inflamed terminal ileum were significantly lower than those obtained from normal ileal segments (14). Dillman et al. (15) have evaluated ADC values using MR enterography including diffusion MRI in 28 pediatric patients diagnosed with Crohn's disease at the time of diagnosis and at 1 and 6-months during treatment. ADC has shown a gradual increase with time $\left(1180 \pm 200 \times 10^{-6} \mathrm{~mm}^{2} / \mathrm{sec}\right.$ at the time of diagnosis, $1420 \pm 420 \times 10^{-6} \mathrm{~mm}^{2} / \mathrm{sec}$ at
1 month following diagnosis, $1450 \pm 450 \times 10^{-6} \mathrm{~mm}^{2} /$ $\mathrm{sec}$ at 6 months following diagnosis, $p=0.0003$ ). Li et al. (16) have reported lower ADC values in inactive bowel segments compared to actively inflamed bowel segments in their study including 25 active and 22 inactive Crohn's disease patients $(p<0.001)$. ADC threshold value was found to be $1170 \times 10^{-6} \mathrm{~mm}^{2} / \mathrm{sec}$ and this had $100 \%$ sensitivity and $88 \%$ specificity to discriminate active and inactive Crohn's patients.

In accordance with the previous data, our study has also demonstrated statistically significant difference regarding ADC measurements when compared between normal and diseased bowel segments, as well as between diseased bowel segments at active inflammation and remission phases, independent from age and gender. In our study, we compared ADC values of left parailiac lymph node obtained from diffusion MRI at the time of active disease and 6 months later at remission, in a 36-year-old male diagnosed with ulcerative colitis and rectosigmoid involvement. ADC values increased after treatment from $806 \times 10^{-6} \mathrm{~mm}^{2} / \mathrm{sec}$ to $994 \times 10^{-6} \mathrm{~mm}^{2} / \mathrm{sec}$. There are several limitations of our study. First, since our study lacks a healthy control group, we failed to detect a threshold to define healthy and pathological ADC values. Second, comparison with control MRI was only performed in the first group, since control MRI was not performed due to patient loss at follow-up. Therefore, in the second group of patients, healthy bowel segments were used for comparison instead of segments at remission.

\section{CONCLUSION}

IBD is diagnosed at early adulthood, courses with relapses and requires routine follow-up. Radiation exposure is important during follow-up. Our findings are in favor of the use of diffusion MRI along with MR enterography to assess inflammation at the time of diagnosis and follow-up and to evaluate the response to treatment.

Conflict of interest: Authors declare that there is no conflict of interest between the authors of the article.

Financial conflict of interest: Authors declare that they did not receive any financial support in this study.

Address correspondence to: Seyit Erol, Necmettin Erbakan University, Meram Faculty of Medicine, Department of Radiology, 42090, Konya, Turkey

E-mail: seyiterol42@gmail.com

Phone number: 05432989069 


\section{REFERENCES}

1. Kaymakoğlu S. Inflamatuvar barsak hastalıkları. Gastroenterohepatoloji. 1. Baskı. Nobel Tıp Kitabevi;2001:47.

2. Maglinte DD, Lappas JC, Kelvin FM, et al. Small bowel radiography: How, when, and why? Radiology 1987;163:297305.

3. Herlinger $\mathrm{H}$. Textbook of gastrointestinal radiology. Philadelphia 2001:766-88.

4. Umschaden HW, Gasser J. MR enteroclysis. Radiol Clin North Am 2003;41(2):231-48.

5. Wills JS, Lobis IF, Denstman FJ. Crohn disease: State of the art. Radiology 1997;202(3):597-610.

6. Koç G. Crohn hastalığı tanı ve takipte MR enterografi yönteminin etkinliği. (Uzmanlık tezi) İzmir 2012.

7. Siddiki H, Fidler J. MR imaging of the small bowel in Crohn's disease. Eur J Radiology 2009;69(3):409-17.

8. Gore RM, Ghahremani GG. Radiologic investigation of acute inflammatory and infectious bowel disease. Gastroenterol Clin North Am 1995;24(2):353-84.

9. Potthast $S$, Rieber $A$, Von Tirpitz $C$, et al. Ultrasound and magnetic resonance imaging in Crohn's disease: A comparison. Eur Radiol 2002;12(6):1416-22.

10. Qi C, Zhang S, Liu Y, et al. Evaluation of Crohn's disease activity with multi-slice CT enterography. Zhonghua Yi Xue Za Zhi 2015;95(25):2006-9.
11. Koh DM, Collins DJ. Diffusion-weighted MRI in the body: Applications and challenges in oncology. AJR Am J Roentgenol 2007;188(6):1622-35.

12. Seo N, Park SH, Kim KJ, et al. MR enterography for the evaluation of small-bowel inflammation in crohn disease by using diffusion-weighted imaging without intravenous contrast material: A prospective noninferiority study. Radiology 2016;278(3):762-72.

13. Kim KJ, Lee $\mathrm{Y}$, Park $\mathrm{SH}$, et al. Diffusion weighted MR enterography for evaluating Crohn's disease: How does it add diagnostically to conventional MR enterography? Inflamm Bowel Dis 2015;21(1):101-9.

14. Foti PV, Farina R, Coronella M, et al. Crohn's disease of the small bowel: Evaluation of ileal inflammation by diffusionweighted MR imaging and correlation with the Harvey Bradshaw index. Radiol Med 2015;120(7):585-94.

15. Dillman JR, Smith EA, Sanchez R, et al. DWI in pediatric small-bowel crohn disease: Are apparent diffusion coefficients surrogates for disease activity in patients receiving infliximab therapy? AJR Am J Roentgenol 2016;207(5):1002-8.

16. Li X, Sun C, Mao R, et al. Assessment of activity of crohn disease by diffusion-weighted magnetic resonance imaging. Medicine (Baltimore) 2015;94(43):1819. 